\title{
UPAYA MENINGKATKAN MOTIVASI BELAJAR SISWA MELALUI PENGGUNAAN MEDIA VIDEO PEMBELAJARAN BERBASIS POWERPOINT DI SMK NEGERI 2 SITUBONDO
}

\author{
DWI USTIK DIANA \\ SMK Negeri 2 Situbondo \\ Email : ustikurip@gmail.com
}

\begin{abstract}
This descriptive study aims to determine the motivation of learning achievement between learning using powerpoint-based learning videos and without using powerpoint-based learning videos.Comparatively aims to determine the difference in learning achievement of physics between powerpoint-based learning videos between powerpoint-based learning using learning and without powerpoint-based learning videos.This research is a quasi experimental conducted at SMK Negeri 2 Situbondo in 2020/2021. The results of descriptive research show that the tendency of learning achievement in physics taught using powerpoint-based learning video is in the very high category. The result of the analysis show that there is a significant difference in learning achievement between using powerpoint-based learning videos and without using powerpoint-based learning videos. The average achievement of learning physics using powerpoint-based learning videos is higher than learning without using powerpointbased learning videos. So it can be concluded that learning using powerpoint-based learning videos is more effective than learning without powerpoint-based learning videos.
\end{abstract}

Keyword: powerpoint-based learning videos, motivation, learning achievement

\section{PENDAHULUAN}

Pendidikan merupakan kunci untuk semua kemajuan dan perkembangan yang berkualitas, karena pendidikan dapat diartikan sebagai sebuah proses dengan metode-metode tertentu sehingga orang memperoleh pengetahuan, pemahaman dan cara bertingkah laku yang sesuai dengan kebutuhan (Syah, 2010: 10). Pendidikan dalam era modern semakin tergantung tingkat kualitas antisipasi dari para guru untuk menggunakan berbagai sumber yang tersedia mengatasi permasalahan yang dihadapi siswa. Salah satu faktor yang menentukan dalam meningkatkan prestasi belajar siswa adalah kemampuan guru dalam memilih media pembelajaran. Selain itu, guru pun harus mampu menentukan suatu media pembelajaran yang tepat dengan suatu materi yang hendak disampaikan. Oleh karena itu, seorang guru harus menguasi atau minimal mengetahui keunggulan dan kekurangan dari media pembelajaran yang digunakan ditinjau dari cara belajar siswa, kondisi dan situasi sekolah, sarana dan prasarana yang ada. Media adalah segala bentuk alat fisik yang dapat menyajikan pesan serta merangsang siswa untuk belajar (Briggs, 1970 dalam Sadiman, 2008 ,6). Media adalah segala sesuatu yang dapat digunakan untuk menyalurkan pesan dari pengirim ke penerima sehingga dapat merangsang pikiran, perasaan, perhatian dan minat serta perhatian siswa sedemikian rupa sehingga proses belajar terjadi (Sadiman, 2008:7)

Dalam menjalankan perannya, guru harus mampu menggunakan media pembelajaran dengan baik untuk memotivasi siswa dalam belajar. Namun fakta yang ditemukan di lapangan, masih terdapat beberapa siswa yang kurang dalam motivasi ketika belajar terutama selama pembelajaran secara daring. Siswa kurang memiliki motivasi yang menyebabkan siswa merasa bosan dan jenuh ketika melakukan pembelajaran, beberapa siswa bermalas- malasan dan fokus dengan kegiatan sendiri tanpa memperhatikan kegiatan yang sedang berlangsung. Jika kondisi ini terus berlanjut pada siswa, maka tidak ideal guru memberikan pembelajaran. Dengan berjalannya perkembangan ilmu pengetahuan dan teknologi, penggunaan media pendidikan, khususnya media video sudah merupakan tuntutan yang mendesak. Hal ini disebabkan sifat pembelajaran yang kompleks. terdapat berbagai tujuan belajar yang sulit dicapai hanya dengan 
mengandalkan penjelasan guru. Oleh karena itu, agar pembelajaran dapat mencapai hasil yang maksimal diperlukan adanya pemanfaatan media, salah satunya media video.

Video merupakan serangkaian gambar gerak yang disertai suara yang membentuk suatu kesatuan yang dirangkai menjadi alur, dengan pesan-pesan di dalamnya untuk ketercapaian tujuan pembelajaran yang disimpan dengan proses penyimpanan pada media pita atau disk (Arsyad, 2004:36 dalam Rusman dkk 2011:218).Video merupakan media audio visual yang menampilkan gerak (Sadiman, 2008:74).Oleh karena itu, guru dapat menggunakan media pembelajaran berupa video pembelajaran berbasis power point dalam melakukan proses belajar mengajar dalam meningkatkan minat belajar siswa. Microsoft Office Power Point menyediakan fasilitas slide untuk menampung pokok-pokok pembicaraan yang akan disampaikan pada peserta didik. Dengan fasilitas animasi, suatu slide dapat dimodifikasidengan menarik. Begitu juga dengan adanya fasilitas : front picture, sound, dan effect dapat dipakai untuk membuat suatu slide yang bagus. Sehingga, mengakomodasi sesuai dengan modalitas belajar siswa. Program ini dapat mengakomodasi siswa yang memiliki tipe visual, auditif, maupun kinestetik (Rusman dkk, 2013: 297). Menurut Rusman dkk (2013: 295)Microsoft Power Point merupakan program aplikasi presentasi yang populer dan paling banyak digunakan saat ini untuk berbagai kepentingan presentasi, baik pembelajaran, presentasi produk, meeting, seminar, lokakarya dan sebagainya. Menurut Sukiman (2011: 213) Microsoft Power Point merupakansalah satu produk unggulan Microsoft Corporation dalam program aplikasi presentasi yang paling banyak digunakan saat ini. Hal ini dikarenakan banyak kelebihan di dalamnya dengan kemudahan yang disediakan. Pemanfaatan media presentasi ini dapat digunakan oleh pendidik untuk mempresentasikan materi pembelajaran ataupun tugas- tugas yang akan diberikan. Penggunaan Media pembelajaran berupa video pembelajaran berbasis power point ini dapat meningkatkan minat belajar siswa, karena dapat menyajikan materi dalam bentuk video, gambar dan tulisan. Sehingga mudah dilihat dan ditirukan oleh peserta didik.

Permasalahan dilapangan yang perlu diperhatikan adalah Kemampuan guru, karena media pembelajaran merupakan bahan atau alat yang digunakan untuk menyampaikan materi pembelajaran dalam berbagai bentuk yang dapat memberikan rangsangan peserta didik untuk belajar. Kenyataan menunjukkan bahwa guru masih mengalami kendala dalam menggunakan media pembelajaran. Penulis merasa ada beberapa alasan mengapa penggunaan media pembelajaran masih minim. Alasan tersebut antara lain tidak tersedianya media pembelajaran di sekolah, guru yang tidak mau repot dalam mempersiapkan media pembelajaran, mahalnya dalam pengadaan media dan kurangnya waktu dalam mempersiapkan media. Penulis juga merasa bahwa ada muatan dalam pembelajaran yang kurang diminati peseta didik. Salah satunya yaitu pembelajaran fisika. Hal ini disebabkan karena persepsi peserta didik bahwa fisika merupakan pembelajaran yang didalamnya hanya rumus saja. Sebenarnya ada beberapa materi yang membutuhkan percobaan namun media tidak tersedia. Hal tersebutlah yang menyebabkan rendahnya motivasi peserta didik terhadap pembelajaran Fisika.

Video pembelajaran berbasis powerpoint memiliki potensi besar dalam mempengaruhi masa depan pembelajaran dan terus tumbuh serta dapat diintegrasikan dalam berbagai pembelajaran, termasuk pembelajaran fisika. Penelitian ini meninjau dan mensintesa penggunaan dan pengembangan video dalam pendidikan fisika berdasarkan temuan melalui studi literatur, serta mengidentifikasi peluang pengembangan video dimasa depan. Hasil penelitian mengungkapkan penggunaan video dalam pembelajaran fisika efektif meningkatkan hasil belajar siswa dan mendorong siswa aktif dalam pembelajaran. Format video dapat disusun sesuai kebutuhan pembelajaran fisika. Video memiliki kelebihan dan kekurangan dalam penggunaannya, sehingga dibutuhkan keterampilan pendidik dalam memaksimalkan kelebihan dan meminimalisir kekurangannya. Video pembelajaran fisika telah banyak dikembangkan pada materi-materi fisika, yang seluruhnya telah valid untuk digunakan sebagai media pembelajaran. Perkembangan teknologi memberikan peluang bagi penelitian selanjutnya untuk dapat mengembangkan video dengan software yang tersedia serta menyebarluaskan hasil pengembangan video. 


\section{METODE PENELITIAN}

Penelitian ini termasuk jenis penelitian Quasi experiment atau eksperimen semu. Penelitian dilaksanakan di SMK Negeri 2 Situbondo tahun pelajaran 2020/2021. Variabel pada penelitian ini adalah variabel bebas (pembelajaran dengan media video pembelajaran berbasis powerpoint dengan pembelajaran tanpa media video) dan variabel terikat (prestasi belajar fisika). Desain penelitian yang digunakan adalah pretest-posttest control group design. Populasi dalam penelitian ini yaitu siswa kelas XAKPR SMK Negeri 2 Situbondo tahun ajaran 2020/2021 yang berjumlah 31 orang. Teknik pengambilan sampel dengan random sampling. Sampel penelitian adalah kelas $\mathrm{X}$ AKPR sebagai kelas kontrol $(\mathrm{N}=31)$ dan kelas $\mathrm{X}$ TAV sebagai kelas eksperimen $(\mathrm{N}=31)$. Instrumen yang digunakan adalah tes pilihan ganda yang mewakili indikator kompetensi dasar dan angket motivasi yang menggunakan skala Likert yaitu dengan menggunakan rentang mulai dari pernyataan sangat positif sampai pernyataan sangat negatif menurut Arikunto (2002).

Data penelitian dianalisis dengan menggunakan statistik deskriptif untuk menunjukkan deskripsi motivasi dan hasil belajar. Nilai tes meliputi rerata, nilai tertinggi, nilai terendah, dan persentase perubahan pretest dengan posttest. Selain itu data skor variabel terikat ditampilkan dalam bentuk grafik.

\section{HASIL PENELITIAN}

Tabel 1. Deskripsi Nilai Pretest - Posttest hasil Belajar Siswa Kelas X SMK Negeri 2 Situbondo

\begin{tabular}{|l|l|l|l|l|}
\hline \multirow{2}{*}{ Statistik } & \multicolumn{2}{|l|}{ Kelas Kontrol } & Kelas Eksperimen \\
\cline { 2 - 5 } & Pretest & Posttest & Pretest & Postest \\
\hline Nilai Tertinggi & 60 & 100 & 60 & 90 \\
\hline Nilai Terendah & 20 & 60 & 20 & 60 \\
\hline Rata - Rata & 40 & 80 & 40 & 75 \\
\hline Median & 40 & 80 & 40 & 75 \\
\hline Standar Deviasi & 14,61 & 13,25 & 16,92 & 12,01 \\
\hline
\end{tabular}

Tabel.1 diatas menunjukkan statistik nilai hasil belajar siswa sebelum menggunakan media video berbasis power point antara kelas eksperimen dan kelas kontrol.

Tabel 2. Distribusi Kategori Prosentase hasil belajar Siswa Kelas X SMK Negeri 2 Situbondo

\begin{tabular}{|l|l|l|l|l|l|l|l|l|}
\hline \multirow{3}{*}{ Statistik } & \multicolumn{4}{l}{ Kelas Kontrol } & \multicolumn{4}{l|}{ Kelas Eksperimen } \\
\cline { 2 - 9 } & Pretest & \multicolumn{3}{l}{ Posttest } & \multicolumn{2}{l|}{ Pretest } & \multicolumn{2}{l|}{ Posttest } \\
\cline { 2 - 9 } & F & $\%$ & F & $\%$ & F & $\%$ & F & $\%$ \\
\hline Sangat Tinggi & 0 & 0 & 8 & 25,81 & 0 & 0 & 9 & 29,03 \\
\hline Tinggi & 0 & 0 & 12 & 38,71 & 0 & 0 & 12 & 38,71 \\
\hline Sedang & 8 & 25,81 & 11 & 35,48 & 9 & 29,03 & 10 & 32,26 \\
\hline Rendah & 18 & 48,39 & 0 & 0 & 9 & 29,03 & 0 & 0 \\
\hline $\begin{array}{l}\text { Sangat } \\
\text { Rendah }\end{array}$ & 8 & 25,81 & 0 & 0 & 13 & 41,94 & 0 & 0 \\
\hline Jumlah & 31 & 100 & 31 & 100 & 31 & 100 & 31 & 100 \\
\hline
\end{tabular}

Tabel-2 diatas menunjukkan statistik dari distribusi prosentase hasil belajar siswa sebelum menggunakan media video berbasis power point antara kelas eksperimen dan kelas kontrol. 


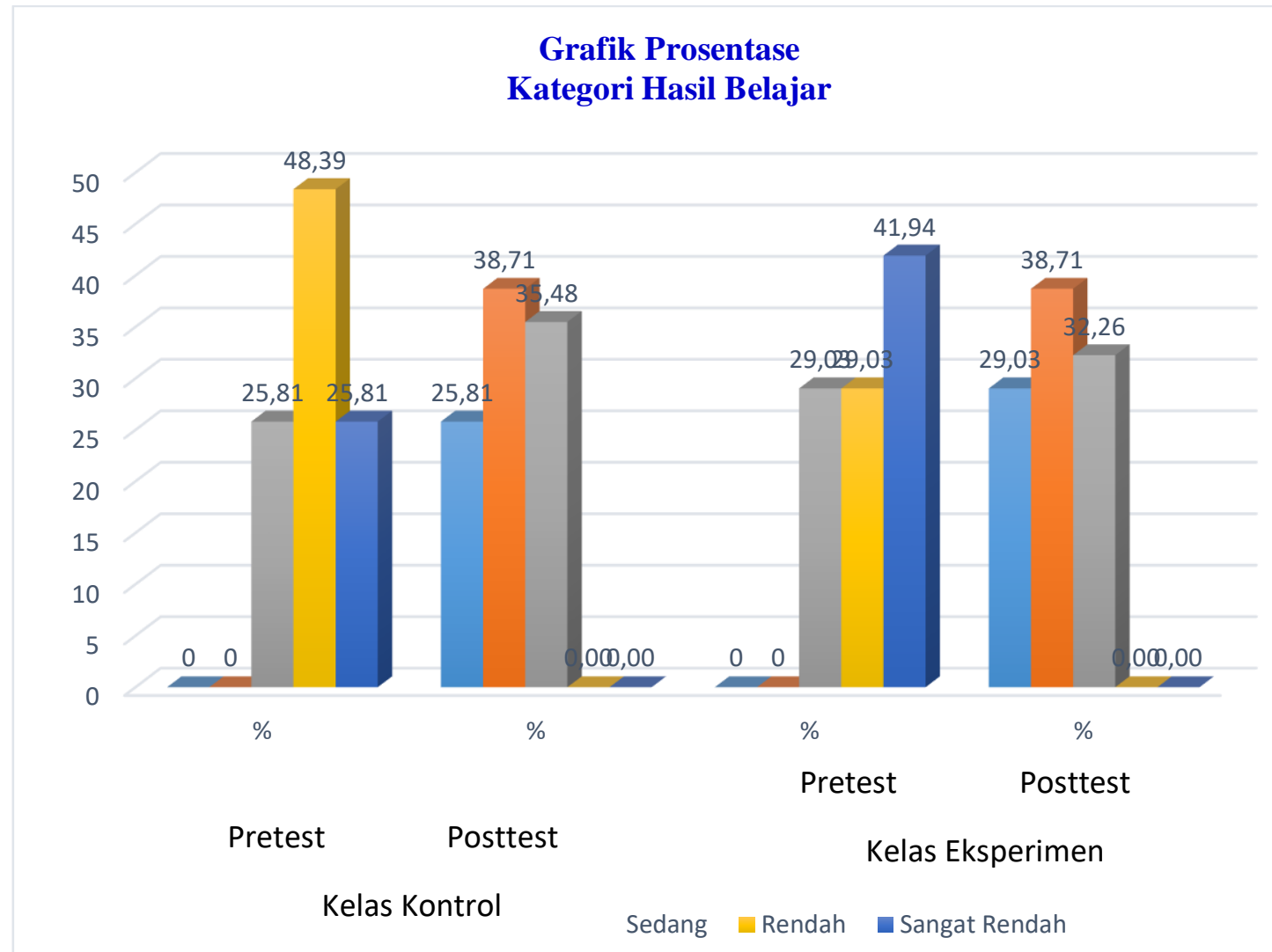

Gambar 1. Distribusi Kategori Presentase Hasil Belajar Siswa Kelas X SMK Negeri 2 Situbondo

Tabel 3. Deskripsi Nilai Pretest-Posttest Motivasi Belajar Siswa Kelas X SMK Negeri 2 Situbondo

\begin{tabular}{|l|l|l|l|l|}
\hline \multirow{2}{*}{ Statistik } & Kelas Kontrol & Kelas Eksperimen \\
\cline { 2 - 5 } & Pretest & Posttest & Pretest & Postest \\
\hline Nilai Tertinggi & 70 & 100 & 70 & 95 \\
\hline Nilai Terendah & 40 & 75 & 40 & 65 \\
\hline Rata - Rata & 55 & 87,5 & 55 & 80 \\
\hline Median & 55 & 87,5 & 55 & 80 \\
\hline Standar Deviasi & 8,26 & 6,24 & 10,44 & 9,23 \\
\hline
\end{tabular}

Tabel.3 diatas menunjukkan statistik nilai hasil belajar siswa setelah menggunakan media video berbasis power point antara kelas eksperimen dan kelas kontrol.

Tabel 4. Distribusi Kategori Prosentase motivasi belajar Siswa Kelas X SMK Negeri 2 Situbondo

\begin{tabular}{|l|l|l|l|l|l|l|l|l|}
\hline \multirow{2}{*}{ Statistik } & \multicolumn{9}{l}{ Kelas Kontrol } & \multicolumn{2}{l}{ Kelas Eksperimen } \\
\cline { 2 - 9 } & \multicolumn{2}{|l|}{ Pretest } & Posttest & \multicolumn{2}{l|}{ Pretest } & \multicolumn{2}{l|}{ Posttest } \\
\cline { 2 - 9 } & F & $\%$ & F & $\%$ & F & $\%$ & F & $\%$ \\
\hline Sangat Tinggi & 0 & 0 & 22 & 70,97 & 0 & 0 & 15 & 48,39 \\
& & & & & & & & \\
\hline Tinggi & 9 & 29,03 & 9 & 29,03 & 8 & 25,81 & 16 & 51,61 \\
\hline Sedang & 21 & 67,74 & 0 & 0 & 16 & 51,61 & 0 & 0 \\
\hline Rendah & 1 & 3,23 & 0 & 0 & 7 & 22,58 & 0 & 0 \\
\hline Sangat Rendah & 0 & 0 & 0 & 0 & 0 & 0 & 0 & 0 \\
\hline Jumlah & 31 & 100 & 31 & 100 & 31 & 100 & 31 & 100 \\
\hline
\end{tabular}


Tabel-4 diatas menunjukkan statistik dari distribusi prosentase motivasi belajar siswa setelah menggunakan media video berbasis power point antara kelas eksperimen dan kelas kontrol.

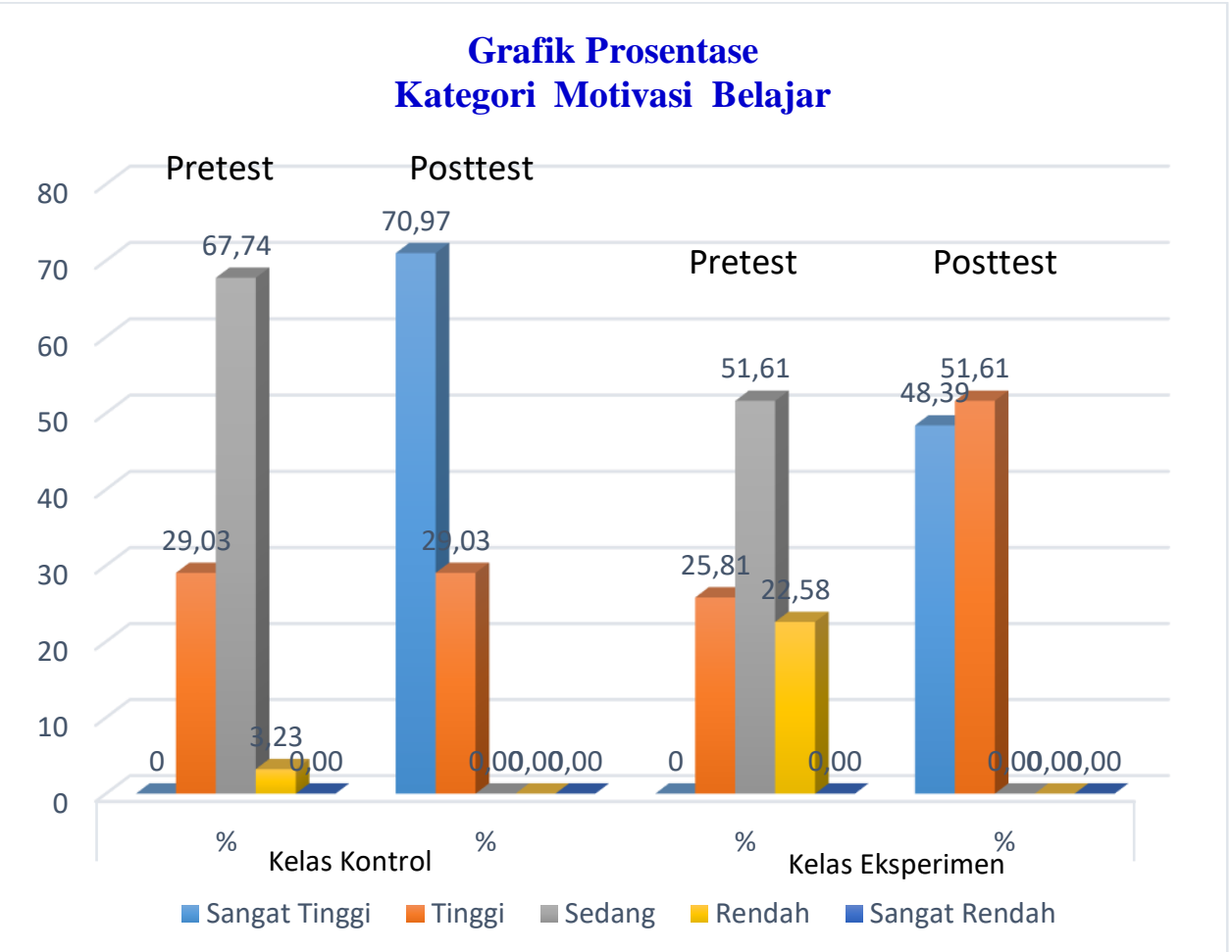

Gambar 2. Grafik Prosentase Kategori Motivasi Belajar

\section{PEMBAHASAN}

Berdasarkan tabel 1 data hasil belajar siswa untuk kelas kontrol menunjukkan skor rata-rata yang diperoleh siswa untuk pretest adalah 40 pada kategori rendah dan untuk posttest adalah 80 pada kategori tinggi. Data hasil belajar siswa untuk kelas eksprimen menunjukkan skor rata-rata untuk pretest 40 yang berada pada kategori sedang dan untuk posttest adalah 75 yang berada pada kategori tinggi.

Pada kelas eksperimen, hasil belajar siswa pada saat pemberian pretest dikategorikan dalam 3 kategori, yaitu kategori sedang, rendah dan sangat rendah, dimana presentase hasil belajar siswa berturut-turut adalah sebesar $(25,81 \%),(48,39 \%),(25,81 \%)$. Begitu pula pada hasil posttest, hasil belajar siswa dapat dikelompokan dalam tiga kategori yakni sangat tinggi, tinggi, dan sedang. Jumlah siswa pada kelas eksperimen adalah 31 orang, dimana presentase hasil belajar yang berada dalam kategori sangat tinggi sebesar 29,03\%. Presentase hasil belajar siswa pada kategori tinggi adalah $38,71 \%$, sedangkan pada kategori sedang sebesar $32,86 \%$ dan kategori rendah setelah pemberian posttest, adalah $0 \%$.

Berdasarkan tabel 3 data motivasi belajar siswa untuk kelas kontrol menunjukkan skor rata-rata yang diperoleh siswa untuk pretest adalah 55 pada kategori tinggi dan untuk posttest adalah 87,5 pada kategori tinggi. Data motivasi belajar siswa untuk kelas eksprimen menunjukkan skor rata-rata untuk pretest 55 yang berada pada kategori sedang dan untuk posttest adalah 80 yang berada pada kategori tinggi.

Pada kelas eksperimen, motivasi belajar siswa pada saat pemberian pretest dikategorikan dalam tiga kategori, yaitu ketegori tinggi, sedang dan rendah dimana presentase hasil belajar siswa berturut-turut adalah sebesar $(25,81 \%),(51,61 \%)$ dan $(22,58 \%)$, sedangkan pada hasil posttest, hasil belajar siswa dapat dikelompokan dalam dua kategori yakni sangat tinggi dan tinggi. Jumlah siswa pada kelas eksperimen adalah 31 orang, dimana presentase motivasi belajar yang berada dalam kategori sangat tinggi sebesar 48,39\% dan pada kategori tinggi adalah 51,61\%. Berdasarkan uji beda yang dilakukan dari masing-masing variabel dapat 
terlihat angka signifikan untuk variabel kelompok hasil belajar dan motivasi belajar kelas XTAV dan Kelas X AKPR SMK Negeri 2 Situbondo.

Perlakuan yang berbeda di masing-masing kelas menunjukkan adanya pengaruh media video terhadap hasil belajar peserta didik, berdasarkan hasil data diatas dapat diketahui bahwa terjadi peningkatan hasil belajar antara kedua kelas baik kelas setelah menggunakan media video berbasis power point. Adanya video pembelajaran mempermudah peserta didik memahami materi pelajaran fisika dengan lebih jelas dan konkrit. Keseluruhan materi dalam video pembelajaran dapat memancing peserta didik untuk bertanya lebih jauh tentang materi yang diberikan yaitu mengenai konsep yang lebih luas. Hal ini sesuai dengan pernyataan Hamalik (2008) yang mengemukaan bahwa pemakaian media pembelajaran dalam proses mengajar dapat membangkitkan keinginan dan minat yang baru, membangkitkan motivasi dan rangsangan kegiatan belajar. Adanya video pembelajaran ini dapat menjadi solusi bagi tenaga pendidik dalam memfasilitas kebutuhan peserta didik dalam proses belajar mengajar sesuai dengan latar belakang masalah.

Kelas eksperimen setelah perlakuan menggunakan media video menunjukkan hasil belajar yang lebih baik dari pada kelas yang menggunakan PDF, penggunaan video pada proses pembelajaran membuat siswa lebih termotivasi dan lebih antusias dibanding dengan menggunakan PDF. Selain pemberian video peserta didik juga diberikan LKPD untuk dikerjakan secara berkolompok. Dengan adanya LKPD tersebut siswa menjadi lebih interaktif. Pada tahap ini peserta didik dilatih untuk mengevaluasi hasil dari teman yang lain dan dilatih untuk membuat sebuah kesimpulan dari materi yang telah diajarkan. Dalam membuat sebuah kesimpulan peserta didik akan berpikir dan berusaha mencari jawaban yang benar untuk memberikan argument yang logis. Seluruh aspek tersebut terakomodasi dalam diskusi interaktif saat masing-masing kelompok menyampaikan hasil pengamatan dan diskusinya. Guru dan siswa akan melakukan refleksi terhadap proses kegiatan pembelajaran guna memperbaiki dan menyempurnakan kegiatan pembelajaran berikutnya.

Perbedaan cara guru dalam menyampaikan materi bertujuan untuk mengetahui pengaruh penggunaan media video terhadap motivasi belajar peserta didik. Sebelum kegiatan penelitian dilakukan, maka terlebih dahulu dilakukan pre-test dengan pembagian angket motivasi kepada peserta didik. Angket motivasi berisi seperangkat pertanyaan atau pernyataan tertulis kepada responden untuk dijawabnya. Pre-test dilakukan untuk mengetahui motivasi belajar peserta didik sebelum diberikan perlakuan. Setelah peserta didik diberi perlakuan, pada pertemuan terakhir pembelajaran fisika besaran di lakukan pos-test untuk mengetahui pengaruh penggunaan media yang di gunakan di setiap kelompok. Post-test untuk mengetahui pengaruh media yang digunakan juga menggunakan angket motivasi seperti pada saat pre-test.

Di dalam Pendidikan motivasi mempunyai peranan penting, dengan membangkitkan motivasi anak terangsang untuk menggunakan potensi-potensi yang dimiliki secara konstruktif dan produktif mencapai tujuan, dan tujuan itu dianggap sebagai kebutuhan yang harus diraihnya. Agar anak didik terangsang untuk menggunakan potensi-potensi yang dimiliki secara konstruktif dan produktif untuk mencapai tujuan. Guru harus mampu mengembangkan motivasi tepat pada setiap anak didik pada waktu belajar. Guru berusaha mencarikan cara bagaimana potensi belajar yang ada didalam diri anak didik itu muncul dengan sendirinya dengan rangsangan-rangsangan yang diberikan oleh guru.guru. Banyak cara yang dapat dilakukan guru agar potensi yang dimiliki siswa termotivasi pada waktu belajar, menciptakan persaingan yang sehat antara sesame siswa waktu belajar, menimbulkan rasa puas terhadap apa yang dia pelajari dan terhadap hasil yang ia peroleh dan memberikan pujian.

Motivasi memiliki peran utama terhadap peningkatan hasil belajar siswa. Motivasi dapat diperoleh dari dalam (intrinsik) maupun dari luar (ekstrinsik). Salah satu prinsip motivasi yaitu motivasi berasal dari dalam individu lebih efektif daripada yang dipaksakan dari luar. Motivasi ekstrinsik berupa motivasi dari guru sangat dibutuhkan dalam proses belajar mengajar di kelas namun, terkadang guru hanya memberi motivasi dengan pujian pada siswa yang memiliki prestasi dalam akademik saja, sehingga yang menerima motivasi tersebut 
adalah mereka yang cerdas secara akademik matematis, padahal kita telah pahami bahwa kecerdasan memiliki banyak aspek. Disisi lain anak-anak yang diberi gelar bodoh dan nakal akan semakin terpuruk melalui sikap yang ditunjukkan oleh guru kepada mereka ketika berinteraksi. Hal ini sejalan dengan Slavin (2009) Motivasi intrinsik siswa pada umumnya menurun dari sekolah dasar tahun-tahun pertama hingga sekolah menengah, karena alasan ini sekolah menerapkan berbagai insentif ekstrinsik (extrinsic incentive), yaitu imbalan untuk pembelajaran yang tidak melekat dalam bahan yang sedang dipelajari Imbalan ekstrinsik dapat berkisar dari pujian, nilai, penghargaan, hingga hadiah atau imbalan lain. Sejalan dengan Sansone (2000) Fenomena motivasi intrinsik mencerminkan kecenderungan utama manusia untuk terlibat dalam kegiatan yang menarik perhatian mereka untuk belajar, mengembangkan dan memperluas kapasitas mereka. Motivasi intrinsik yang terkandung setiap kali orang berperilaku untuk kepuasan yang melekat dalam perilaku itu sendiri.

\section{KESIMPULAN}

Berdasarkan hasil penelitian yang dilakukan di SMK Negeri 2 Situbondo dapat disimpulkan bahwa motivasi dan hasil belajar siswa yang dibelajarkan dengan media PDF berada pada Kategori tinggi dengan nilai rata-rata sebesar 80 dan 75.Motivasi dan hasil belajar siswa yang dibelajarkan dengan media video berbasis powerpoint berada pada kategori tinggi dengan nilai rata-rata sebesar 87,5 dan 80 . Rerata prestasi belajar kelas pada pembelajaran menggunakan media video pembelajaran berbasis powerpoint lebih tinggi dibandingkan dengan kelas yang penggunakan pembelajaran tanpa menggunakan video berbasis powerpoint. Sehingga, pembelajaran menggunakan media video pembelajaran berbasis powerpoint lebih efekrtif digunakan untuk pembelajaran fisika dibandingkan dengan pembelajaran tanpa menggunakan media video pembelajaran berbasis powerpoint. Ada Pengaruh penggunaan media video pembelajaran berbasis powerpoint terhadap motivasi dan hasil belajar siswa dengan nilai yang signifikan.

\section{DAFTAR PUSTAKA}

Arikunto, S. (2009). Dasar-Dasar Evaluasi Pendidikan (Edisi Revisi). Jakarta: Bumi Aksara. Arsyad, A. (2013). Media Pembelajaran. Jakarta: PT. Raja Grafindo Persada.

Arief Sadiman. (2008). Media Pembelajaran: Pengertian, Pengembangan dan Pemanfaatannya. Jakarta: Raja Grafindo Persada

Daryanto. (2010). Media pembelajaran peranannya sangat penting dalam mencapai tujuan pembelajaran. Yogyakarta: Gava Media.

Hamalik, O. (2008). Proses Belajar Mengajar. Jakarta: Bumi Aksara.

Lubis, S. P. W. (2017). Pengaruh Penggunaan Video Pembelajaran Terhadap Hasil Belajar Siswa Kelas XII. Jurnal Dedikasi. Vol 1 (2).

Pujiyanto \& Widodo B. (2015). Efektivitas Penggunaan Media Pembelajaran terhadap Prestasi Belajar Fisika.

Resky, A. (2018). Pengaruh Penggunaan Video Pembelajaran Terhadap Motivasi dan Hasil Belajar Siswa Pada Materi Sistem Peredaran Darah

Rusman, dkk. (2013). Pembelajaran Berbasis Teknologi Informasi dan Komunikasi Mengembangkan Profesionalitas Guru. Jakarta: Rajawali Pers

Sansone, C., Judith, M \& Harackiewicz. (2000). Intrinsic and extrinsic motivation: The search for optimal motivation and performance. San Diego: Academic Press.

Sukiman. (2011). Pengembangan Media Pembelajaran. Yogyakarta: Pustaka Insan Madani 